\title{
Occurrence of toxigenic Aspergillus flavus in commercial Bulgur wheat
}

\author{
Carla Bertechini FARIA ${ }^{1 \ddagger}$, Fabiane Cristina dos SANTOS ${ }^{1 \ddagger}$, Fausto Fernandes de CASTRO ${ }^{1 \ddagger}$, \\ Ariadne Ricieli SUTIL ${ }^{1}$, Luciana Marciano SERGIO ${ }^{1}$, Milena Veronezi SILVA², Miguel MACHINSKI JUNIOR², \\ Ione Parra BARBOSA-TESSMANN ${ }^{1 *}$
}

\begin{abstract}
Aflatoxins are mutagenic, carcinogenic, and teratogenic mycotoxins. The objective of this work was to study the presence of aflatoxigenic Aspergillus in commercial Bulgur wheat in the city of Maringá, Paraná, Brazil. Thirty samples of commercial Bulgur wheat, acquired in the period of August 2011 to January 2012, were evaluated. The enumeration analysis showed that samples had up to 273.3 CFU of molds and 133.3 CFU of aflatoxigenic Aspergillus per gram of wheat. Forty-two monosporic isolates were obtained and identified as Aspergillus flavus. The isolates were analyzed regarding their aflatoxigenic potential by culture in coconut milk agar; hydroxide vapor exposure; chromatography; and polymerase chain reaction (PCR) targeting genes that code enzymes of the aflatoxins synthesis pathway. Some of the isolates were confirmed to be aflatoxin producers and several of them presented a genetic profile of aflatoxin synthesis. The obtained results demonstrated that Bulgur wheat A. flavus contamination is concerning.

Keywords: Aspergillus flavus; aflatoxins; Bulgur wheat; PCR.

Practical Application: Aflatoxicosis associated with consumption of contaminated food is a major concern due to the risk of liver cancer and other diseases. The presence of aflatoxigenic Aspergillus needs to be monitored to evaluate the potential for aflatoxin contamination in food. This study presents methods of screening for aflatoxigenic Aspergillus in commercial Bulgur wheat. In addition, this work offers methods of isolation and identification of the Aspergillus species present in food and methods for testing the aflatoxigenic potential of the isolates.
\end{abstract}

\section{Introduction}

Mold contamination in processed food can occurs pre- and post-harvest, in material processing, in storage, and even due to the environment atmosphere. Filamentous molds, which are usually found in stored cereal grains, are primarily species of the genera Aspergillus, Penicillium, and Fusarium. These molds cause rottenness, deterioration, nutrient loss, organoleptic properties alteration, and shelf-life decrease; moreover, they are capable of producing different types of mycotoxins (Pitt \& Hocking, 1997; Bennett \& Klich, 2003; Richard, 2007).

Molds of the Aspergillus genus are particularly dangerous in two ways: they are opportunistic pathogens that can cause aspergillosis and respiratory system allergies, and they can cause aflatoxicosis due aflatoxin production in food products. Aflatoxins are mainly produced by Aspergillus flavus, Aspergillus parasiticus, and Aspergillus nomius (Richard, 2007; Creppy, 2002). These species are also the most commonly found in several foods, where they can produce aflatoxins in several points of their production chain (Gourama \& Bullerman, 1995; Pitt \& Hocking, 1997). Most A. parasiticus isolates are aflatoxin producers, but only $40-50 \%$ of $A$. flavus isolates produce these mycotoxins (Konietzny \& Greiner, 2003). Aflatoxins are primarily hepatotoxic, immunosuppressant, teratogenic, and mutagenic (Richard, 2007), and have been classified as group I carcinogens by the International Agency for Research on Cancer (International Agency for Research on Cancer, 2002). Susceptibility depends on the species, age, dose, extent of exposure, nutrition, sex, and concomitant exposure to other toxins. The liver is the target organ primarily affected in mammals.

Conventional methods for mold identification and detection in food are based on culture and microscopy, which are timeconsuming and laborious processes. Despite the frequent use of molecular methods for the detection of bacteria in food, few such methods have been developed for mold detection in food. Still, molecular methods have been employed for the identification of several toxigenic molds, including Aspergillus isolates, in culture and non-processed affected cereals. Among these techniques, polymerase chain reaction (PCR) is most frequently employed because it is faster, sensitive, and very specific (Shapira et al., 1996; Geisen, 1996; Färber et al., 1997; Criseo et al., 2001; Niessen, 2007; Abdin et al., 2010).

The evaluation of the incidence of mycotoxigenic mold in food is important because of the strong correlation between mold 
presence and mycotoxin occurrence (González et al., 1998; Lori et al., 2003; Passone et al., 2010). The information resulting from these tests can indicate the hazard analysis critical control point inside the food producer chain (Food and Agriculture Organization of the United Nations, 2001) and allows decision-making measures about the storage time of the analyzed product and the need for specific mycotoxin analysis. Thus, the present work had the objectives of analyzing the presence of Aspergillus in Bulgur wheat commercialized in the city of Maringá, Paraná, which is located in Southern Brazil, the main wheat producer region in this country. Bulgur wheat is a cereal food made from wheat grains and it is used in Mediterranean and Arabic cuisine and is greatly appreciated in Brazil. In addition, this work aimed to obtain monosporic isolates and to molecularly identify them; to evaluate the aflatoxin production profile of the isolates by culture and chromatographic techniques; and to evaluate the aflatoxins production potential from the obtained isolates through PCR reactions targeting genes that code for enzymes from the aflatoxin synthesis pathway.

\section{Materials and methods}

\subsection{Sample collection}

Bulgur wheat samples were bought in stores of the city of Maringá, in the period of August 2011 to January 2012. Five samples were acquired per month, totaling 30 samples, consisting of individual packs of $500 \mathrm{~g}$ each. The samples belonged to 13 different brands and lots and had different expiration dates. All samples were conserved at room temperature and were analyzed before the expiration date. Twelve of the brand industries were from 11 following different municipalities of the Paraná state: Araruna (4 samples), Maringá (4 samples), Cianorte (1 sample), Umuarama (6 samples), Cambará (4 samples), Campo Largo (1 sample), Marilândia do Sul (3 samples), Pinhais (1 sample), Nova Esperança (3 samples), Arapongas (1 sample), and Sarandi (1 sample). One brand industry was from Garça (1 sample), a municipality of São Paulo state. The Paraná state is located in the Southern region of Brazil, which is the main producer of wheat because of its climate. São Paulo state is located in the north border of the Paraná state.

\subsection{Molds and aflatoxigenic Aspergillus enumeration}

Each sample was analyzed by the method of serial dilution for molds and for A. flavus and A. parasiticus enumeration, as described by Pitt \& Hocking (1997). To accomplish this, $20 \mathrm{~g}$ of each sample was suspended in $250 \mathrm{~mL}$ Erlenmeyer flasks containing $80 \mathrm{~mL}$ of sterile $0.1 \%$ peptone water. This suspension was incubated for 1 hour at $25^{\circ} \mathrm{C}$ in an incubator with orbital agitation at $100 \mathrm{rpm}$. Aliquots of $500 \mu \mathrm{L}$ of this suspension were spread in the surface of a $10 \mathrm{~cm}$ diameter Petri dish (in triplicate) containing Aspergillus flavus and parasiticus agar (AFPA): $2 \mathrm{~g} / \%$ yeast extract; $1 \mathrm{~g} / \%$ bacteriologic peptone; $0.05 \mathrm{~g} / \%$ ferric ammonium citrate; and $1.5 \mathrm{~g} / \%$ agar (Pitt \& Hocking, 1997). To prevent fast-growth molds such as Rhizopus and Mucor, malachite green was added to the medium at a proportion of $2.5 \mu \mathrm{g} / \mathrm{mL}$ of medium before autoclaving. To prevent bacterial growth, the medium was aseptically supplemented with $641 \mathrm{UI} / \mathrm{mL}$ of penicillin and $256.4 \mu \mathrm{g} / \mathrm{mL}$ of streptomycin after autoclaving.
The culture dishes were maintained in an incubator with a photoperiod of 12 hours, at $25{ }^{\circ} \mathrm{C}$, for five days. The reverse of colonies of aflatoxigenic Aspergillus presented orange color in this medium. The results were expressed in colony-forming units (CFU) of mold and of aflatoxigenic Aspergillus per gram of wheat sample (CFU/g).

\subsection{Isolation of the A. flavus strains}

An orange color reverse colony agar fragment in the selective AFPA medium was transferred to a tube containing potato dextrose agar (PDA) slant, and cultured at $25^{\circ} \mathrm{C}$, for five days to promote spore formation. After that, a $1 \mathrm{~cm}^{3} \mathrm{PDA}$ culture fragment was agitated and fragmented in $20 \mathrm{~mL}$ of sterile water; $100 \mu \mathrm{L}$ of this suspension containing the spores were spread in $10 \mathrm{~cm}$ diameter dishes containing 2.5\% agar-water medium. After culture at $25^{\circ} \mathrm{C}$ for approximately 16 to 20 hours, a hypha fragment or a single germinating spore was transferred to new PDA slant tubes (Nelson et al., 1983). The isolates are being maintained in PDA slant tubes, at $4{ }^{\circ} \mathrm{C}$, with semester passages.

\subsection{Morphologic identification of the isolates}

For the morphologic identification of the isolates, a sterile wood skewer stick pointed end covered with spores from PDA monosporic cultures was used to inoculate, by touching, three equidistant points in $10 \mathrm{~cm}$ diameter dishes containing Czapek Yeast Extract agar (CYA) (Pitt \& Hocking, 1997). The dishes were maintained at $25^{\circ} \mathrm{C}$ in an incubator with a photoperiod of 12 hours, for 7 days, before analysis.

For the taxonomic classification of each isolate, the following features were observed: macroscopic colony surface and reverse characteristics (format, diameter, coloration, and texture) and microscopic aspects (conidia format and size; vesicle, conidiophore, and phialide characteristics). The observed characteristics were used for classification, according to the proper dichotomous keys described by Pitt \& Hocking (1997).

\subsection{DNA extraction}

To obtain mycelia without spores for the DNA extraction of the isolates, a fragment of approximately $1 \mathrm{~cm}^{3}$ of a monosporic culture in a PDA slant was cut into smaller pieces and agitated in $5 \mathrm{~mL}$ of sterile distilled water. Two milliliters of the obtained suspension ( $3.84 \times 10^{7}$ of spores), without the agar fragments, were used to inoculate $125 \mathrm{~mL}$ Erlenmeyer flasks containing $25 \mathrm{~mL}$ of liquid AFP medium without malachite green or antibiotics. These flasks were incubated for 5 days in an incubator, without agitation, at $25^{\circ} \mathrm{C}$, with a photoperiod of 12 hours. The obtained mycelia were collected by filtration in sterile gauze and used for DNA extraction.

For the DNA extraction, the obtained mycelial mass was macerated with liquid nitrogen in a porcelain mortar with pestle until transformation in a fine powder. Approximately $300 \mu \mathrm{L}$ of this powder was transferred to a microtube and the DNA was extracted with the method described by Koenig et al. (1997) with two additional steps of organic solvent washes. Quickly, after lysis with $700 \mu \mathrm{L}$ of the lysis buffer and incubation at $65^{\circ} \mathrm{C}$ for $60 \mathrm{~min}$, 
the mixture was extracted once with $500 \mu \mathrm{L}$ of Tris equilibrated phenol, once with $500 \mu \mathrm{L}$ of Tris equilibrated phenol:choroform $(1: 1, \mathrm{v} / \mathrm{v})$, and once with $500 \mu \mathrm{L}$ of chloroform:isoamylic alcohol $(24: 1, \mathrm{v} / \mathrm{v})$. After treatment with RNAse A and proteinase K, the DNA was then precipitated with isopropanol, collected by centrifugation, and the DNA pellet was washed three times with cold $70 \%$ ethanol. The final DNA pellet was dried and ressuspended with $100 \mu \mathrm{L}$ of TE buffer and stored at $-20^{\circ} \mathrm{C}$. The whole process was carried out under sterile conditions. The DNA was quantified in a spectrophotometer at $260 \mathrm{~nm}$. The DNA final concentration was adjusted to $100 \mathrm{ng} / \mu \mathrm{L}$ in TE buffer.

\subsection{Molecular identification of the isolates}

The molecular identification of the isolates was performed via the amplification of a 5.8S-ITS rDNA fragment with the primers ITS4 5'-TCCTCCGCTTATTGATATGC and ITS5 5 '-GAAGTAAAAGTCGTAACAAGG described by White et al. (1990). The amplification reactions were performed using a Techne TC-312 thermocycler (England) in PCR tubes containing $25 \mu \mathrm{L}$ of the following reaction mixture: $50 \mathrm{mM} \mathrm{KCl} ; 10 \mathrm{mM}$ Tris, $\mathrm{pH} 7.5 ; 1.5 \mathrm{mM} \mathrm{MgCl}_{2} ; 1.5 \mathrm{U}$ of Platinum Taq DNA polymerase; $0.2 \mathrm{mM}$ of each dNTP; $25 \mathrm{pmol}$ of each primer; and 50 to $400 \mathrm{ng}$ of the DNA sample. The PCR reaction consisted of 25 cycles of $1 \mathrm{~min}$ and 30 seconds at $94^{\circ} \mathrm{C}, 1 \mathrm{~min}$ and 30 seconds at $50^{\circ} \mathrm{C}$, and $2 \mathrm{~min}$ at $72^{\circ} \mathrm{C}$. Previously to the cycles, samples were heated for $5 \mathrm{~min}$ at $94^{\circ} \mathrm{C}$. After the cycles, samples were incubated for $10 \mathrm{~min}$ at $72{ }^{\circ} \mathrm{C}$ and frozen at $-20{ }^{\circ} \mathrm{C}$ until use. Ten $\mu \mathrm{L}$ of the PCR reaction were analyzed in a $1.5 \%$ agarose gel containing ethidium bromide $(0.25 \mu \mathrm{g} / \mathrm{mL})$. The PCR products were visualized and photographed under UV light. Negative controls (no DNA template) were used in each experiment to test for the presence of DNA contamination of reagents and reaction mixtures. The amplified fragment $(\sim 600 \mathrm{pb})$ was purified with the PureLink ${ }^{\mathrm{m}}$ PCR purification kit (Life Technologies, USA), sequenced at the Center for Human Genome Studies (CEGH) of the University of São Paulo (USP), and the obtained sequence was compared with sequences deposited in data banks.

\subsection{Aflatoxin production analysis via culture techniques}

The aflatoxin production potential of the isolates was evaluated through the production of fluorescence under ultraviolet (UV) light in the culture in coconut milk agar (CMA). This medium was prepared with $200 \mathrm{~mL}$ of coconut milk (Indiano - Jaf Agro Pecuaria Industria e Comercio Ltda - ME, Parnamirim, RN, Brazil), $600 \mathrm{~mL}$ of distilled water, $\mathrm{pH} 6.9$, and $16 \mathrm{~g}$ of agar (Lin \& Dianese, 1976). Plastic Petri dishes of $9 \mathrm{~cm}$ in diameter containing approximately $20 \mathrm{~mL}$ of CMA, in triplicate, were inoculated in the center with one touch of the pointed end of a sterile wood skewer stick covered with spores. The dishes were incubated at $28^{\circ} \mathrm{C}$, up to 7 days, with a photoperiod of 12 hours, and fluorescence was observed in a UV transilluminator with emission at $312 \mathrm{~nm}$.

For the ammonium hydroxide vapor analysis, the dishes of CMA with a 7-day-old colony were inverted and drops of ammonium hydroxide were added in the internal side of the lid. The production of aflatoxins was visualized by the appearance of pink color in the white medium around and in the reverse of the isolates' colonies (Saito \& Machida, 1999).

Positive controls for these and all other analyses of aflatoxin production were the isolates $A$. parasiticus UEM 443, previously isolated from peanuts, and A. flavus NRRL 5940.

\subsection{Aflatoxin production analysis by thin layer chromatography (TLC)}

A fragment of approximately $1 \mathrm{~cm}^{3}$ of a monosporic culture in a PDA slant was cut in smaller pieces and was agitated in $10 \mathrm{~mL}$ of sterile distilled water. One hundred microliters of the obtained suspension $\left(9.6 \times 10^{5}\right.$ of spores $)$, without the agar fragments, were spread in $10 \mathrm{~cm}$ diameter dishes containing malt glucose agar (MGA) [5\% (w/v) malt extract, $5 \%(\mathrm{w} / \mathrm{v})$ glucose, $2 \%(\mathrm{w} / \mathrm{v})$ agar] or CMA medium. The dishes were incubated at $28^{\circ} \mathrm{C}$ for 7 days. Only one dish was cultured and analyzed for each isolate.

With the use of a sterilized cork borer, eight disks of $0.5 \mathrm{~cm}$ in diameter were cut from each medium and independently transferred to two microtubes (four disks each), where they were fragmented, and $500 \mu \mathrm{L}$ of chloroform was added (Criseo et al., 2001). This mixture was agitated at $100 \mathrm{rpm}$ for $60 \mathrm{~min}$ at room temperature and the agar fragments containing the mycelia were discarded. The resulting extracts were joined and passed through a small column made with a blue $1.0 \mathrm{~mL}$ common pipette tip. This column tip had glass wool in the bottom end and was filled with $1.5 \mathrm{~g}$ of anhydrous sodium sulfate $\left(\mathrm{Na}_{2} \mathrm{SO}_{4}\right)$, which was covered with small pieces of filter paper. The eluate was dried at room temperature and the obtained residue was re-suspended in $20 \mu \mathrm{L}$ of chloroform.

Approximately $10 \mu \mathrm{L}$ of the extract obtained from MGA or CMA cultures were added to TLC plates (Silica gel, Sigma-Aldrich, Germany). The application dots were dried at room temperature and the chromatogram was developed in a solvent system of toluene-ethyl acetate-chloroform-formic acid (7:5:5:2). The reference isolates A. parasiticus UEM 443 and A. flavus NRRL 5940 were analyzed in the same way. The aflatoxin standards were acquired from Sigma-Aldrich (Germany). The aflatoxin B1 and B2 standards were dissolved in toluene at $0.125 \mu \mathrm{g} / \mu \mathrm{L}$ and the aflatoxin $\mathrm{G} 1$ and $\mathrm{G} 2$ standards were dissolved in methanol:water $(9: 1, v / v)$ at the same concentration.

\subsection{Aflatoxin production analysis by high performance liquid chromatography (HPLC)}

One hundred microliters of the spore suspension $\left(9.6 \times 10^{5}\right.$ of spores), obtained as above, from each isolate were used to inoculate a $125 \mathrm{~mL}$ flask containing $25 \mathrm{~mL}$ of the Yeast Extract Sucrose (YES) medium (2\% yeast extract and $20 \%$ sucrose) (Davis et al., 1966). The flasks were incubated at $28^{\circ} \mathrm{C}$, without agitation, for 14 days. Only one flask was cultured and analyzed for each isolate. After this period, the content of each flask was filtered using common filter paper. Ten milliliters of hexane were added to the filtrate and shaken in a vortex for $1 \mathrm{~min}$. The organic fraction was discarded and $10 \mathrm{~mL}$ of chloroform were added to the aqueous fraction. After agitation in the vortex 
for $3 \mathrm{~min}$, the mixture was left to rest until the layers separated. The organic fraction of chloroform was collected and filtered in filter paper containing anhydrous sodium sulfate. The solvent was evaporated by incubation at $50{ }^{\circ} \mathrm{C}$ overnight and the residue was stored at $4^{\circ} \mathrm{C}$ until analysis.

The obtained residue was re-suspended in $1 \mathrm{~mL}$ of methanol:water (1:1), passed through a $0.45 \mu \mathrm{m}$ syringe filter, and $100 \mu \mathrm{L}$ were injected into a Finnigan Surveyor Plus HPLC System (Thermo Scientific, USA). A fluorescence detector, which was set at 365 $\mathrm{nm}$ excitation and $430 \mathrm{~nm}$ emission for aflatoxins B1 and B2, was used. The chromatographic column was the Pickering C18 (Pickering Laboratories, USA), with the following parameters: $4.6 \times 150 \mathrm{~mm}, 5 \mu \mathrm{m}$, and a temperature of $25^{\circ} \mathrm{C}$. The mobile phase was water:acetonitrile $(65: 35 \mathrm{v} / \mathrm{v})$ with a flow rate of 1 $\mathrm{mL} / \mathrm{min}$. A standard comprising a mix of the aflatoxins $\mathrm{B} 1$ and B2 was used to construct a five-point calibration curve of peak areas versus concentration. The detection limit of the method was $1 \mu \mathrm{g} / \mathrm{L}$, and the recovery rate was $85.5 \%$.

\subsection{Genotyping the Aspergillus isolates for aflatoxin biosynthesis pathway genes}

The aflatoxigenic potential of the Aspergillus isolates was first evaluated by genotyping with single PCR reactions with a pair of primers designed by Shapira et al. (1996): APA-450 5' -TATCTCCCCCCGGGCATCTCCCGG and APA-1482 5'-CCGTCAGACAGCCACTGGACACGG, which amplify a DNA fragment of 1,032 bp of the apa-2 gene from A. parasiticus; and three pair of primers described by Geisen (1996): omt1 5'-GTGGACGGACCTAGTCCGACATCAC and omt2 5'-GTCGGCGCCACGCACTGGGTTGGGG, which amplify a DNA fragment of $797 \mathrm{bp}$ from the omt-A gene of $A$. parasiticus; ver1 5'-GCCGCAGGCCGCGGAGAAAGTGGT and ver2 5'-GGGGATATACTCCCGCGACACAGCC, which amplify a DNA fragment of $537 \mathrm{bp}$ from the $A$. parasiticus ver-1 gene; and nor1 5' -ACCGCTACGCCGGCACTCTCGGCAC and nor2 5'-GTTGGCCGCCAGCTTCGACACTCCG, which amplify a DNA fragment of 400 bp of the A. parasiticus nor-1 gene. The amplification reactions were performed as described above for the ITS primers, excepting that the PCR reaction consisted of 35 cycles and the annealing temperature was $65^{\circ} \mathrm{C}$. Negative controls (no DNA template) were also used in each experiment. Negative reactions were repeated at least twice. Negative reactions for the pair of primers APA-450/1482 and omt1/2 were also performed with an annealing temperature of $62{ }^{\circ} \mathrm{C}$, except for the isolates 1-3 and 17-2. This lower annealing temperature was used to decrease primer specificity and evaluate probable mutation in the target gene instead of absence. Positive controls for gene amplification were DNA from the producer isolates $A$. parasiticus UEM 443 and A. flavus NRRL 5940.

\subsection{Statistical analysis}

Statistical analyses were carried out by calculation of the means and standard deviations of the results and comparison with the Tukey test $(\alpha<0.01)$, using the program SAS (SAS Institute, Cary, NC, USA).

\section{Results}

\subsection{Sample mold and aflatoxigenic Aspergillus enumeration}

Molds and aflatoxigenic Aspergillus counting were transformed in CFU/g of Bulgur wheat and are shown in Table 1. The counting values obtained for molds (average $87.8 \pm 22.7$ ), were significantly higher than the values obtained for Aspergillus (average $28.8 \pm 7.32$ ). Samples that had no molds counted also had no Aspergillus counted. It seems that the more samples were mold contaminated, the more samples were Aspergillus contaminated. However, there were exceptions to this; for instance, sample 29 was heavily contaminated with molds but had no Aspergillus contamination.

\subsection{Isolation and identification of the Aspergillus isolates}

Forty-two monosporic isolates were obtained. All of the obtained isolates had morphological characteristics of A. flavus or A. parasiticus (Table 1). The molecular identification by sequencing of the amplified 5.8S-ITS rDNA gene fragment and comparison with sequences deposited in GenBank identified all the isolates as A.flavus. The obtained sequences were deposited in GenBank and the accession numbers are listed in Table 1.

\subsection{Aflatoxin production by culture techniques}

The obtained results of the aflatoxin production screening by culture are presented in Table 2. The yellow-green fluorescence was evidenced around the colony and the pink color was evidenced inside and/or around the colony. Only one (2.38\%) of the isolates (isolate 24-1) was considered as an aflatoxin producer, according to the CMA fluorescence and hydroxide vapor exposure analyses. Three isolates presented blue fluorescence (isolates 2-2, 11-1, and 18-1) but were negative for aflatoxin production in the ammonium hydroxide vapor exposure analysis. An example of a positive result is shown in Figure 1.

\subsection{Aflatoxin production analysis by TLC and HPLC}

The obtained results in the TLC analysis from cultures in MGA and CMA medium are shown in Table 2. The A. flavus isolate 24-1 was the only isolate that produced the aflatoxin B1 when cultured in CMA, as seen in the TLC (Table 2, Figure 2). The A. parasiticus UEM 443 control isolate produced the aflatoxins B1, B2, G1, and G2 and the A. flavus NRRL 5940 control isolate produced only the aflatoxins B1 and B2 in the TLC analyses.

The obtained results in the HPLC analysis from cultures in YES medium are also shown in Table 2. The isolates of A. flavus 12-3, 15-1, 20-1, and 30-1 produced the aflatoxin B1 $(0.159,0.126,0.181$, and $0.190 \mu \mathrm{g} / \mathrm{mL}$, respectively). The isolates $12-3$ and 20-1 also produced the aflatoxin B2 (0.0011 and $0.0016 \mu \mathrm{g} / \mathrm{mL}$, respectively). The $A$. parasiticus UEM 443 and A. flavus NRRL 5940 control isolates produced the aflatoxins B1 (379.936 and $262.352 \mu \mathrm{g} / \mathrm{mL}$, respectively) and B2 (31.716 and $8.708 \mu \mathrm{g} / \mathrm{mL}$, respectively) in the HPLC analyses. Aflatoxins G1 and G2 were not evaluated by HPLC. 
Table 1. Molds and aflatoxinogenic Aspergillus counting per g of sample and obtained isolates.

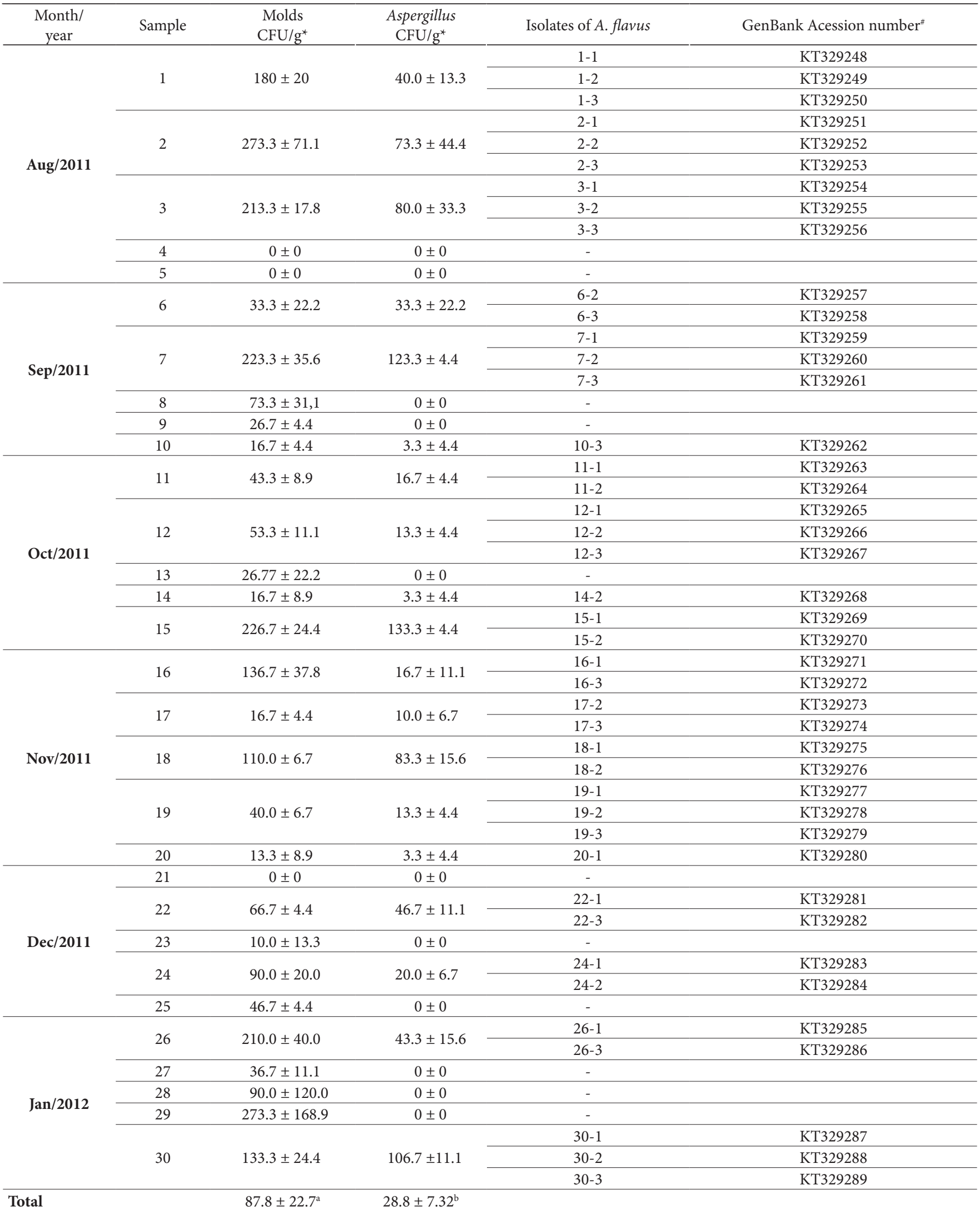

${ }^{*}$ The data are given in CFU/g of Bulgur wheat sample and represent the average and the standard deviation obtained in the analysis of three dishes. \#The isolates were identified by using the ITS region. a,b Statistically different by the Tukey test $(\alpha=0.01)$. 
Table 2. Aflatoxin production screening by culture in CMA, by ammonium hydroxide vapour exposure, by Chromatography (TLC and HPLC), and by PCR.

\begin{tabular}{|c|c|c|c|c|c|c|c|c|c|}
\hline \multirow[b]{2}{*}{ Isolate } & \multirow{2}{*}{$\begin{array}{c}\text { Fluorescence } \\
\text { in } \mathrm{CMA}^{*}\end{array}$} & \multirow{2}{*}{$\begin{array}{l}\text { Ammonium } \\
\text { hydroxide } \\
\text { vapour }^{*}\end{array}$} & \multicolumn{2}{|c|}{ TLC } & \multirow{2}{*}{$\begin{array}{c}\text { HPLC } \\
\text { YES } \\
\end{array}$} & \multicolumn{4}{|c|}{ PCR } \\
\hline & & & MGA & CMA & & $a p a-2$ & omt-A & ver-1 & nor -1 \\
\hline $1-1$ & - & - & - & - & - & + & + & + & + \\
\hline $1-2$ & - & - & - & - & - & + & + & + & + \\
\hline $1-3$ & - & - & - & - & - & - & - & + & - \\
\hline $2-1$ & - & - & - & - & - & + & + & + & + \\
\hline $2-2$ & - & - & - & - & - & + & + & + & + \\
\hline $2-3$ & - & - & - & - & - & + & + & + & + \\
\hline $3-1$ & - & - & - & - & - & - & + & + & + \\
\hline $3-2$ & - & - & - & - & - & + & + & + & + \\
\hline $3-3$ & - & - & - & - & - & + & + & + & + \\
\hline $6-2$ & - & - & - & - & - & - & + & + & + \\
\hline $6-3$ & - & - & - & - & - & - & + & + & + \\
\hline $7-1$ & - & - & - & - & - & + & + & + & + \\
\hline $7-2$ & - & - & - & - & - & + & + & + & + \\
\hline $7-3$ & - & - & - & - & - & + & + & + & + \\
\hline $10-3$ & - & - & - & - & - & + & + & + & + \\
\hline $11-1$ & - & - & - & - & - & + & + & + & + \\
\hline $11-2$ & - & - & - & - & - & - & + & + & + \\
\hline $12-1$ & - & - & - & - & - & + & + & + & + \\
\hline $12-2$ & - & - & - & - & - & + & + & + & + \\
\hline $12-3$ & - & - & - & - & + & + & + & + & + \\
\hline $14-2$ & - & - & - & - & - & + & + & + & + \\
\hline $15-1$ & - & - & - & - & + & + & + & + & + \\
\hline $15-2$ & - & - & - & - & - & - & + & + & + \\
\hline $16-1$ & - & - & - & - & - & + & + & + & + \\
\hline $16-3$ & - & - & - & - & - & + & + & + & + \\
\hline $17-2$ & - & - & - & - & - & - & + & + & + \\
\hline $17-3$ & - & - & - & - & - & + & + & + & + \\
\hline $18-1$ & - & - & - & - & - & + & + & + & + \\
\hline $18-2$ & - & - & - & - & - & + & + & + & + \\
\hline $19-1$ & - & - & - & - & - & + & + & + & + \\
\hline $19-2$ & - & - & - & - & - & + & + & + & + \\
\hline $19-3$ & - & - & - & - & - & + & + & + & + \\
\hline $20-1$ & - & - & - & - & + & + & + & + & + \\
\hline $22-1$ & - & - & - & - & - & - & + & + & - \\
\hline $22-3$ & - & - & - & - & - & + & + & + & + \\
\hline $24-1$ & + & + & - & + & - & + & + & + & + \\
\hline $24-2$ & - & - & - & - & - & - & - & + & - \\
\hline $26-1$ & - & - & - & - & - & + & + & + & + \\
\hline $26-3$ & - & - & - & - & - & + & + & + & + \\
\hline $30-1$ & - & - & - & - & + & - & - & + & + \\
\hline $30-2$ & - & - & - & - & - & + & + & + & + \\
\hline $30-3$ & - & - & - & - & - & - & + & + & - \\
\hline $443^{\#}$ & + & + & + & + & + & + & + & + & + \\
\hline $5940^{\#}$ & + & + & + & + & + & + & + & + & + \\
\hline
\end{tabular}

${ }^{*}$ Analysis in triplicate. "A. parasiticus UEM 443 and A. flavus NRRL 5940.

\subsection{PCR reactions}

Examples of the obtained amplifications are shown in Figure 3. The PCR reactions results are shown in Table 2. Thirty-one $(73.8 \%)$ of the obtained isolates had four fragments amplified from their DNA, indicating that they were potentially aflatoxigenic. The other 11 isolates (26.2\%) had at least one DNA fragment amplified. Negative reactions were tested at least twice. The only gene that had a fragment amplified from all isolates' genomic DNA was the ver- 1 gene. The primers directed to the $a p a-2$ gene have produced most of the negative reactions. 

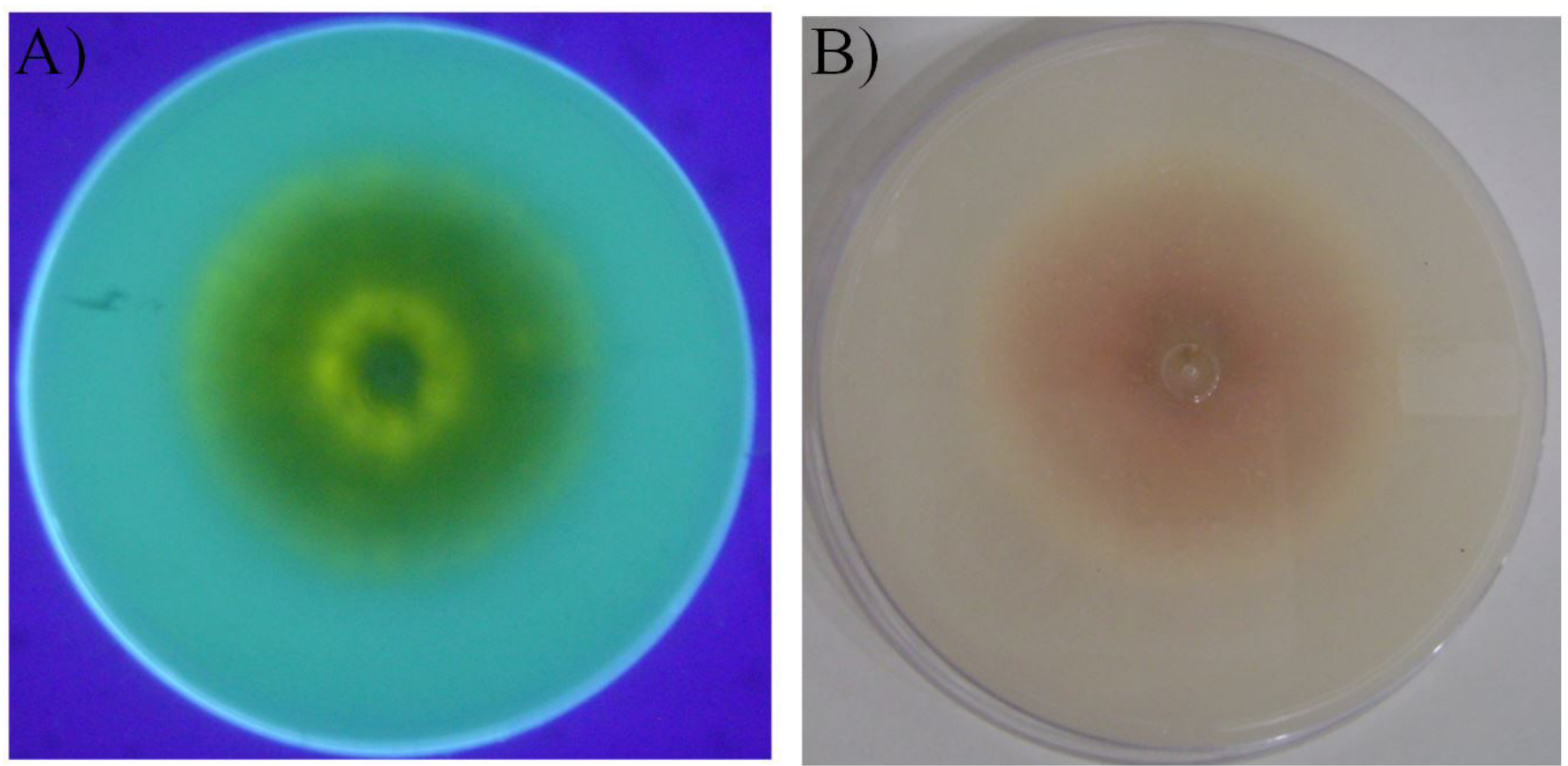

Figure 1. Example of a positive result in the culture techniques. (A) Back of a dish containing CMA medium with a colony of the isolate A. flavus 24-1 photographed under UV light $(312 \mathrm{~nm})$ in a transilluminator; (B) Back of a dish containing CMA medium with a colony of the isolate A. flavus 24-1 exposed to ammonium hydroxide vapor.

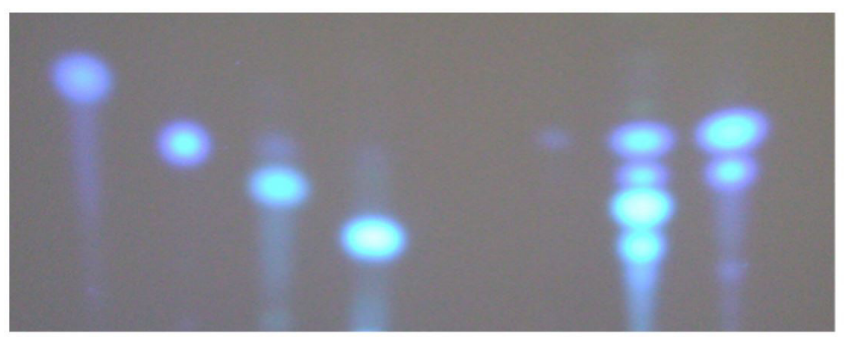

B1 B2 G1 G2

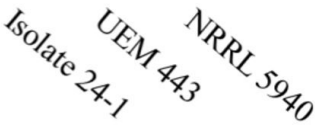

Figure 2. Example of TLC with the extracts produced from cultures in CMA. The plate was photographed under UV light in a transilluminator. $B_{1}, B_{2}, G_{1}$, and $G_{2}$ are standards of aflatoxins (Sigma-Aldrich, Germany).

\section{Discussion}

The data showed that there was high contamination in some samples and very low contamination in other samples from both molds and aflatoxigenic Aspergillus, with a predominance of mold incidence in all tested samples (Table 1). The molecular identification of the obtained monosporic isolates revealed that they were all A. flavus (Table 1). The occurrence of A. flavus and not of $A$. parasiticus was also reported in wheat grown and consumed in Lebanon (Joubrane et al., 2011) and Algeria (Riba et al., 2010).

The detection of aflatoxigenic and non-aflatoxigenic Aspergillus using culture techniques have been described (Lin \& Dianese, 1976; Saito \& Machida, 1999; Abbas et al., 2004). The isolate of A. flavus 24-1 presented a positive result in these methods
(Figure 1). Three other isolates produced blue fluorescence in the CMA and but presented negative results both in the ammonia vapor and TLC analysis. It seems that blue fluorescence should not be considered as a positive result for aflatoxin production.

Traditionally, the most popular method used for mycotoxin analysis is TLC, which offers the ability to screen large numbers of samples in a low-cost manner (Turner et al., 2009; Shephard, 2009). Our TLC results have shown the production of aflatoxin B1 by the isolate of $A$. flavus 24-1 (Figure 2, Table 2), which is in accordance with the literature description of $A$. flavus, which reports only the production of aflatoxins from group B (Richard, 2007). The TLC result was in agreement with the culture analysis in CMA. However, the production of aflatoxins was not seen via TLC, when the isolates were grown in MGA. This may represent differences in the metabolism of the isolates in producing aflatoxins in different media.

The modern analysis of mycotoxins relies heavily on HPLC (Turner et al., 2009; Shephard, 2009). We found four aflatoxin producer isolates using HPLC. The quantitative analysis showed that these isolates did not produce as much as the control isolates of A. parasiticus (UEM 443) and A. flavus (NRRL 5940), in the used conditions. However, we do not know how the isolates would perform in another environment. The aflatoxin producer isolates found using HPLC analysis were not detected as producers in the TLC analysis, and this may reflect differences in medium composition and culture conditions. The literature reports that only $40-50 \%$ of the A. flavus strains produce aflatoxin (Konietzny \& Greiner, 2003). This inability to produce aflatoxins might be due to deletions or other mutations in the aflatoxin biosynthetic genes. In total, only five $(11.9 \%)$ of the obtained isolates were confirmed to produce aflatoxins in the TLC and HPLC analysis (Table 2). 


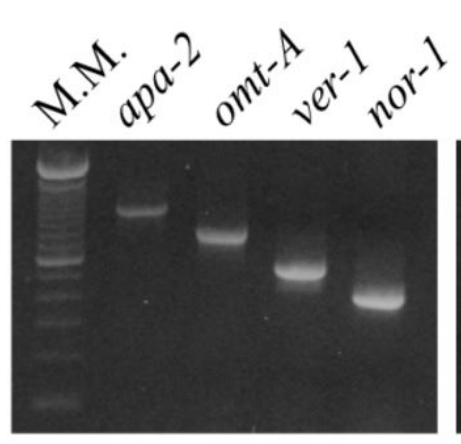

$1-2$

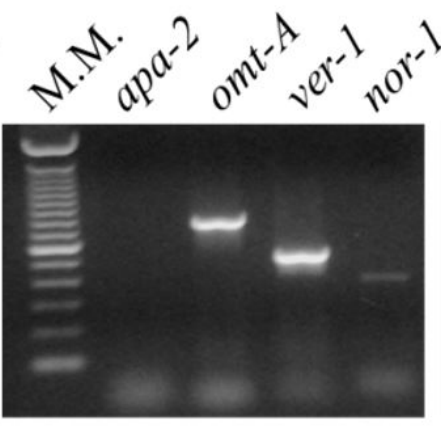

$15-2$

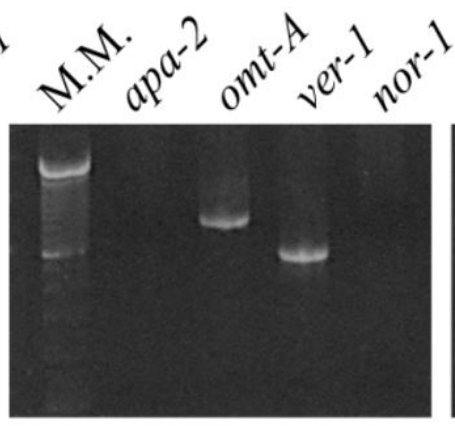

$30-3$

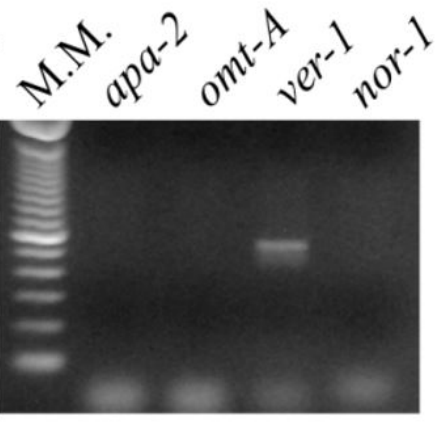

$24-2$

Figure 3. Examples of PCR reaction amplifications. Agarose gel stained with ethidium bromide. M.M. is the 100 bp molecular marker. The reactions with the genomic DNA of the isolates are indicated.

The PCR reactions used in this work have been used to discriminate among aflatoxin-producing and non-producing A. flavus isolates (Färber et al., 1997; Criseo et al., 2001). It has been proposed that the lack of amplification of DNA fragments of one of these genes may signify that the isolate has lost or mutated this gene and is unable to synthesize aflatoxins. Thirty-one $(73.8 \%)$ of the obtained isolates had four amplified DNA fragments in the single PCR reactions used. This indicates that these 31 isolates had the potential to secrete aflatoxins. However, of these 31 isolates, we found that only four were aflatoxin producers. This may be because of the media and culture conditions that were used. In addition, there are more enzymes and genes involved in the aflatoxin synthetic pathway that were not analyzed, and it is possible that one of these genes may not be available for enzyme synthesis.

Among the aflatoxin producer isolates found in this work, only isolate 30-1 had only two DNA fragments amplified in the PCR reaction. The other producer isolates had all four fragments amplified. The DNA fragments that were not amplified from the genomic DNA of isolate 30-1 were fragments from the genes $a p a-2$ and omt- $A$. The DNA fragment from the apa-2 gene was also not amplified from the genomic DNA of several other isolates. We can conclude that these genes may be mutated in isolate 30-1, disallowing PCR amplification with the used primers, but that the coded proteins are still functional. These differences may reflect genetic variations among the A. flavus isolates and indicates that the APA and omt pairs of primers do not have the resolution to separate among aflatoxigenic and non-aflatoxigenic strains.

\section{Conclusions}

Most of the commercial Bulgur wheat samples studied had mold and A. flavus contamination. Beyond the allergenic problems, whenever there is a problem in storage that allows fungal growth, the risk of aflatoxin contamination should be taken into account. The aflatoxin production analyses showed that some of the obtained isolates can produce mycotoxins. Some of the obtained A. flavus isolates showed an aflatoxigenic profile via the amplification of four genes of enzymes involved in aflatoxin synthesis. By better understanding the presence of aflatoxigenic A. flavus in Bulgur wheat, additional tools can be made available to counter the threat aflatoxins pose to food safety and security.

\section{References}

Abbas, H. K., Shier, W. T., Horn, B. W., \& Weaver, M. A. (2004). Cultural methods for aflatoxin detection. Journal of Toxicology. Toxin Reviews, 23(2-3), 295-315. http://dx.doi.org/10.1081/TXR-200027854.

Abdin, M. Z., Ahmad, M. M., \& Javed, S. (2010). Advances in molecular detection of Aspergillus: an update. Archives of Microbiology, 192(6), 409-425. PMid:20358179. http://dx.doi.org/10.1007/s00203-010-0563-y.

Bennett, J. W., \& Klich, M. (2003). Mycotoxins. Clinical Microbiology Reviews, 16(3), 497-516. PMid:12857779. http://dx.doi.org/10.1128/ CMR.16.3.497-516.2003.

Creppy, E. E. (2002). Update of survey, regulation and toxic effects of mycotoxins in Europe. Toxicology Letters, 127(1-3), 19-28. PMid:12052637. http://dx.doi.org/10.1016/S0378-4274(01)00479-9.

Criseo, G., Bagnara, A., \& Bisignano, G. (2001). Differentiation of afatoxin-producing and non-producing strains of Aspergillus flavus group. Letters in Applied Microbiology, 33(4), 291-295. PMid:11559403. http://dx.doi.org/10.1046/j.1472-765X.2001.00998.x.

Davis, N. D., Diener, U. L., \& Eldridge, D. W. (1966). Production of aflatoxin $\mathrm{B} 1$ and $\mathrm{G} 1$ by Aspergillus flavus in semisynthetic medium. Applied Microbiology, 14(3), 378-380. PMid:5970823.

Färber, P., Geisen, R., \& Holzapfel, W. H. (1997). Detection of aflatoxinogenic fungi in figs by aCR reaction. International Journal of Food Microbiology, 36(2-3), 215-220. PMid:9217111. http://dx.doi. org/10.1016/S0168-1605(97)00040-8.

Food and Agriculture Organization of the United Nations - FAO. (2001). Manual on the application of the HACCP system in mycotoxin prevention and control (FAO Food and Nutrition Paper, Vol. 73). Rome: FAO. Retrieved from http:// www.fao.org/3/a-y1390e.pdf

Geisen, R. (1996). Multiplex polymerase chain reaction for the detection of potential aflatoxin and sterigmatocystin producing fungi. Systematic and Applied Microbiology, 19(3), 388-392. http://dx.doi.org/10.1016/ S0723-2020(96)80067-1.

González, H. H. L., Martinez, E. J., Pacin, A., \& Resnik, S. L. (1998). Relationship between Fusarium graminearum and Alternaria alternata contamination and deoxynivalenol occurrence on Argentina durum wheat. Mycopathologia, 144(2), 97-102. PMid:10481289. http:// dx.doi.org/10.1023/A:1007020822134.

Gourama, H., \& Bullerman, L. B. (1995). Aspergillus flavus and Aspergillus parasiticus: aflatoxigenic fungi of concern in foods and feeds: a 
review. Journal of Food Protection, 58(12), 1395-1404. http://dx.doi. org/10.4315/0362-028X-58.12.1395.

International Agency for Research on Cancer - IARC. (2002). Monograph on the evaluation of carcinogenic risks to humans, some naturally occurring substances: some traditional herbal medicines, some mycotoxins, naphthalene and styrene (IARC Monographs, Vol. 82, pp. 171-300). Lyon: IARC. Retrieved from https://monographs. iarc.fr/ENG/Monographs/vol82/mono82.pdf

Joubrane, K., El Khoury, A., Lteif, R., Rizk, T., Kallassy, M., Hilan, C., \& Maroun, R. (2011). Occurrence of aflatoxin B1 and ochratoxin A in Lebanese cultivated wheat. Mycotoxin Research, 27(4), 249-257. PMid:23605926. http://dx.doi.org/10.1007/s12550-011-0101-z.

Koenig, R. L., Ploetz, R. C., \& Kistler, H. C. (1997). Fusarium oxysporum f.sp. cubense consists of a small number of divergent and globally distributed clonal lineages. Phytopathology, 87(9), 915-923. PMid:18945062. http://dx.doi.org/10.1094/PHYTO.1997.87.9.915.

Konietzny, U., \& Greiner, R. (2003). The application of PCR in the detection of micotoxigenic fungi in foods. Brazilian Journal of Microbiology, 34(4), 283-300. http://dx.doi.org/10.1590/S151783822003000400001 .

Lin, M. T., \& Dianese, J. C. A. (1976). Coconut-agar medium rapid detection of aflatoxin production by Aspergillus spp. Phytopathology, 66(12), 1466-1469. http://dx.doi.org/10.1094/Phyto-66-1466.

Lori, G. A., Sisterna, M. N., Haidukowski, M., \& Rizzo, I. (2003). Fusarium graminearum and deoxynivalenol contamination in the durum wheat area of Argentina. Microbiological Research, 158(1), 29-35. PMid:12608577. http://dx.doi.org/10.1078/0944-5013-00173.

Nelson, P. E., Toussoun, T. A., \& Marasas, W. F. O. (1983). Fusarium species: an illustrated manual for identification. University Park: Pennsylvania State University Press.

Niessen, L. (2007). PCR-based diagnosis and quantification of mycotoxin producing fungi. International Journal of Food Microbiology, 119(1-2), 38-46. PMid:17804102. http://dx.doi.org/10.1016/j. ijfoodmicro.2007.07.023.
Passone, M. A., Rosso, L. C., Ciancio, A., \& Etcheverry, M. (2010). Detection and quantification of Aspergillus section Flavi spp. in stored peanuts by real-time PCR of nor-1 gene, and effects of storage conditions on aflatoxin production. International Journal of Food Microbiology, 138(3), 276-281. PMid:20153541. http://dx.doi. org/10.1016/j.ijfoodmicro.2010.01.003.

Pitt, J. I., \& Hocking, A. D. (1997). Fungi and food spoilage. Sydney: Academic Press. http://dx.doi.org/10.1007/978-1-4615-6391-4.

Riba, A., Bouras, N., Mokrane, S., Mathieu, F., Lebrihi, A., \& Sabaou, N. (2010). Aspergillus section Flavi and aflatoxins in Algerian wheat and derived products. Food and Chemical Toxicology, 48(10), 27722777. PMid:20627118. http://dx.doi.org/10.1016/j.fct.2010.07.005.

Richard, J. L. (2007). Some major mycotoxins and their mycotoxicoses: an overview. International Journal of Food Microbiology, 119(1-2), 3-10. PMid:17719115. http://dx.doi.org/10.1016/j.ijfoodmicro.2007.07.019.

Saito, M., \& Machida, S. (1999). A rapid identification method for aflatoxin producing strains of $A$. flavus and $A$. parasiticus by ammonia vapour. Mycoscience, 40(2), 205-208. http://dx.doi.org/10.1007/BF02464300.

Shapira, R., Paster, N., Eyal, O., Menasherov, M., Mett, A., \& Salomon, R. (1996). Detection of aflatoxinogenic molds in grains by PCR. Applied and Environmental Microbiology, 62(9), 3270-3273. PMid:8795215.

Shephard, G. S. (2009). Aflatoxin analysis at the beginning of the twentyfirst century. Analytical and Bioanalytical Chemistry, 395(5), 12151224. PMid:19484460. http://dx.doi.org/10.1007/s00216-009-2857-y.

Turner, N. W., Subrahmanyam, S., \& Piletsky, S. A. (2009). Analytical methods for determination of mycotoxins: a review. Analytica Chimica Acta, 632(2), 168-180. PMid:19110091. http://dx.doi. org/10.1016/j.aca.2008.11.010.

White, T. J., Bruns, T., Lee, S., \& Taylor, J. (1990). PCR protocols, a guide to methods and applications. In M. A. Innis, H. Gelfand, J. J. Sninsky \& T. J. White. PCR protocols: a guide to methods and applications (pp. 315-322). San Diego: Academic Press. 